\title{
The Responses Of Antakya (Antioch) Churches To Cultural Shifts
}

\author{
Yonca Yilmaz ${ }^{1}$, Mine Tanaç Zeren ${ }^{1}$ \\ ${ }^{I}$ Dokuz Eylul University, Faculty of Architecture, Dep. Of Architecture, Program of Restoration
}

Email: yoncayilmaz94@gmail.com

\begin{abstract}
Antakya (Antioch), located in the southern region of Turkey, is one of the oldest settlements in the country. Its history dates back to the prehistoric times. It has been through countless invasions throughout its history. It has been dominated by various civilizations and has been the center of many religions. The city, which was founded by Alexander the Great in the Roman period, has many routes to nearly all directions as a result of its geographical location. Due to its context, this makes the city the point of convergence of cultures. After the Roman period, Byzantine and Arab-dominated city (AC 395 - AC 963), were exposed to constant war between the Christian and Muslim communities for the domination right to the city. Today in Antakya, although the majority of the population is Muslim and Christian, the Sunni Arabs, Sunni Turks, Shia Arabs, Assyrians, Catholics, Orthodox Christians, Protestant Arabs, Arabs, Armenians, Jewish people and other minority groups all live together in harmony, thus forming the dynamics of multicultural city structure. The name "Christian" was first coined in this historic city. Antakya also hosts the Church of Saint Peter, which is believed to be one of the earliest Christian houses of worship, making it extremely valuable for Christianism. Indigenous inhabitants of Antakya have lived in the same land since the foundation of Christianity. Today, 90 percent of the Christians are Orthodox, 10 percent are Protestants and other believers, where the population of Christians are decreasing. Bearing in mind the aforementioned history and context, a research was conducted on the Orthodox Church, Antakya Protestant Church and Vakıflı Armenian Church which all still exist to this day in the city. Purpose of the research is to evaluate the structure of the churches in regards to the following parameters;
\end{abstract}

- The responses of the churches to the indigenous inhabitants

- Cultural shifts in the ever-changing sociocultural values of the society

- The city image they present.

The reason behind choosing these three structures for the study is the fact that all three structures boast Christian symbolism and imagery.

(C) 2019 The Authors. Published by IEREK press. This is an open access article under the CC BY license

(https://creativecommons.org/licenses/by/4.0/).

\section{Keywords}

Antakya (Antioch); Church; Christianity; City Image; Sacred Places

\section{Introduction}

Antakya, which is one of the oldest cities in the country, is a rich city in the aspects of religion. Churches are highly important in this city and Antakya is the first place that the word "Christian" appeared. In the scope of this work, three important church structures for the city were studied and the city/religious buildings' correlation, the effect of 
the buildings on urban identity, meaning of the churches according to the local people and how these churches are being used are narrated through literature review, oral sources and current photographs.

\section{History}

Antakya, which is located in the south of Turkey, is a city with different cultures and hosted lots of civilizations within. The history of the city begins with Prehistoric Age and then followed by Hellenistic Period (333 BC-64 BC). Later, Alexander the Great founded the city's first roots and in this period, Antakya was highly active. The city is on an important trade route because of its geographical position. Being on a trade route and being on a place where Western and Eastern cultures meet have taken an important place on Christianity as it is so common in the city. The birth of Christianity in Antakya goes back to the Roman Age's reach to Arabian Peninsula, getting stronger in this area and taking over the control of trade routes. Because of the pressure of Pagans on the followers of Jesus and Jews who adopt Christianity, these people left Jerusalem and migrated to cities, such as Cyprus and Antakya. Antakya became the biggest city of The Roman Empire, therefore, it was suitable for Jews who follow Jesus to make propaganda, and Barnabas came to the city in $38 \mathrm{AD}$ and found out that he can propagate the discipline of Jesus, and he used Antakya as a center to spread with Pavlos. Barnabas and Pavlos created a large community who accepted the discipline of Jesus in a short period of just one year. These communities who left Paganism and accepted the principle of Jesus in Antakya, were the first people to be called "Christians". The religious life and views of this Christian community in Antakya influenced the Pagan Roman world and from there Christianity spread to the Roman world (Bahadir, 2013). With Peter's stay in Antakya from 52 to 60, Christianity is deeply rooted here. In the historical process, it has become one of the oldest patriarchate centers of Christianity which were raised in numbers to at first three, and then to five, and has played an important role in the discussions within Christianity. After Roman Period, the city was taken over by Byzantines and Arabs (395-963 AD) and was exposed to wars of domination between Christian and Muslim societies (Tekin, 2000). After the Principalities and Crusaders Period (1085-1517 AD), various structures were built in the Ottoman Period (1516-1919). There are 24 mosques and 3 churches amongst its religious buildings. After the Ottoman Period, occupation and the French mandate period came (1919-1937) and then Antakya was annexed by the Turkish Republic. In the middle of the 19th century, due to the work of Firka-1 İslahiye, Cevdet Pasha found the number of households in Antakya and its vicinity and made a religious distribution. According to Cuinet, 10,000 Muslims, 3,500 Christian United Greeks and Greek Orthodox, 3,784 Catholics and Gregorian Armenians live in Antakya. (Religions and History Treasures)

\section{Churches Today}

In addition to the Catholic wing of Christianity in, the other sects have their sacred spaces. First of all, St. Pierre church is located in Neccar Mountain foot. Known since the beginning of Christianity St. Pierre Church, it was built by St. Peter, one of Jesus' disciples. He came to Antakya in the years 29-30 B.C. and used the cave in the mountain as a gathering place in his sermons for the spread of Christianity. Secondly, there is a Protestant Church on Saray Caddesi and today in the Protestant Church, there is a priest who is responsible of the Church. Furthermore, Orthodox Churches are on Hürriyet and Zenginler District. The Orthodox Church, located on Hürriyet Street, is said to be the oldest and the most beautiful of the Eastern Orthodox churches after Jerusalem. It is stated that there are approximately 1200 to 1300 Christian population in Hatay, the majority of which are formed by the Orthodox sect, and even the Catholic community does not have much of the Catholic Church. The other church is called Catholic, It is located in Kurtuluş street in the city center of Antakya. In addition, There are Armenian churches in Hatay in Vakıflı and İskenderun. The study will focus on Vakıflı Armenian Church which is located in the last Armenian village. (Government of Hatay)

\section{The Orthodox and Orthodox Church in Hatay}

Saray Street is a historical street located in the protected area zone. (Figs. 1) The pedestrian axis, which was closed to traffic in 2013, was named as Hürriyet Street. The Orthodox Church is a historical church on the Hürriyet Street. Today Hürriyet, Street is the most active part of the historical city. A number of restoration applications have been 
made in the area where the old houses of Antakya are densely located. In this context, historic houses and inns were renovated. The area, where cafes and shops are frequent, is commercially essential.

Antakya Church, which was first built from wood in 1833, was destroyed in the 1872 earthquake and burnt. There is no proper information about the construction and architecture of the destroyed church. In 1875 the church started to be rebuilt and the construction continued until 1900s. In 1931, the church bell was built. Today, the Orthodox Church is built with masonry stone structural system and it is the largest church of the East due to it being the center of the Patriarchate. (Hatay-Şehri Kutsalım)

The access to the dwelling is from a high arched portal. Five steps from the street level takes us to the courtyard door. Access to the forecourt is via stairs leading from the entrance door.

The church building is located opposite side of the access door and was built in the French style. It is surrounded by two story buildings. On the right side of the church, there is a bell tower.

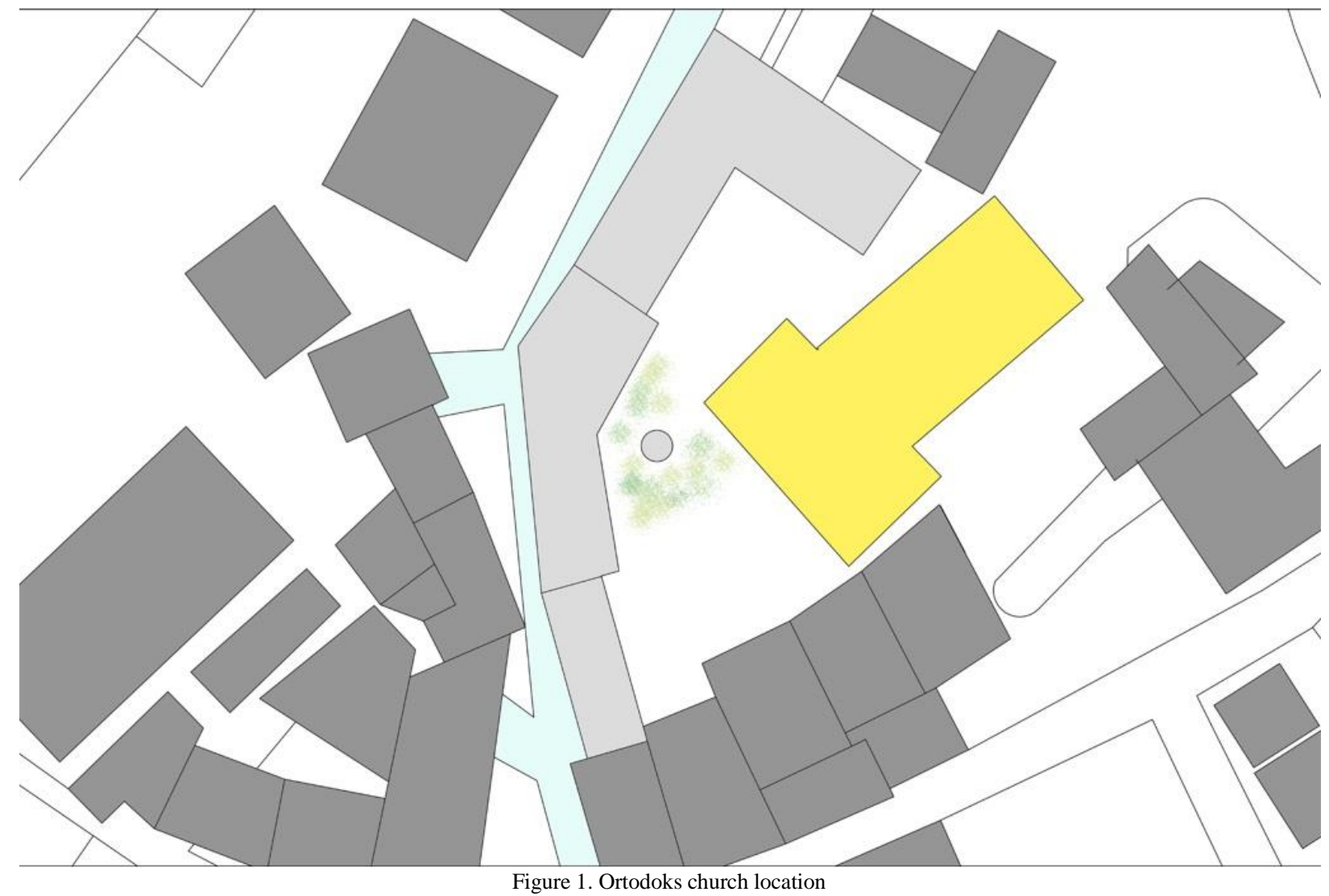

On the south, there are kitchen and outbuildings which have access from the same level of courtyard. On the west, there are rooms for priests of the church and Board of Trustees of the Foundation. The passage to the east wing rooms are via stairs from the forecourt.

Rooms overlook the Saray Street and the lower floors open to the street level and are used as shops with a commercial function. On the north of the church, there is a seminary and this seminary is used as a meeting hall with a hall which was built near in 1999. Between the church and seminary, there is a second courtyard which is separated from the main courtyard with trees. This open area has a fountain and an ornamental pool.

The church is a three naved basilical plan scheme. The main entrance door is between two columns of $70 \times 70 \mathrm{~cm}$. The interior has ten columns and the apse is elevated at the end of the middle nave, and there is a circular skylight above apse.

The church is available for praying today. The ceremony, which is active in church function, is held twice a day in the morning and in the evening. The disembarking Orthodox community tries to protect their traditions and customs 
in the same way. Holy Birth, Holy Resurrection, the Feast of the Assumption of Mary and the name day of the church is still being celebrated.

The church, which has a commercial and touristic area in its vicinity, attracts many tourists with this feature. The fact that the shops belong to the church is an important source of income for the church. Locating in the tourism region increased the visibility of the church in terms of urban identity.

\section{The Protestants and Protestant Church in Hatay}

The Protestant Church located in the historical protected area of Antakya is a corner building between Fevzi Çakmak Street and Saray Street. (Figs. 2) The building, which is in the center of the city, is two minutes walking distance to the pedestrian zone of the Saray Street. It is surrounded by the government building, historical Antakya houses, historical inns and as a result of a number of restorations, is located in a practical place of the city.

The building was first built as a French consulate in the 1800s was later used as a Syrian Bank. It was used as a private residence between 1940 and 1970. Following 1970, the Provincial Police Department used the structure as a police house until 1980. In 1999, the historical building was bought by South Koreans and converted into a church and restored in 2000. (Hatay-Şehri Kutsalım)

The building is surrounded by garden walls with black iron bars along the facade. The entrance, which goes up from the street elevation with five steps, opens to the garden of the building. The building has two gardens. The first one is used as the entrance, the second is at the back of the building used for a cafe. There is a second staircase for the building entrance in the garden and goes to the main entrance.

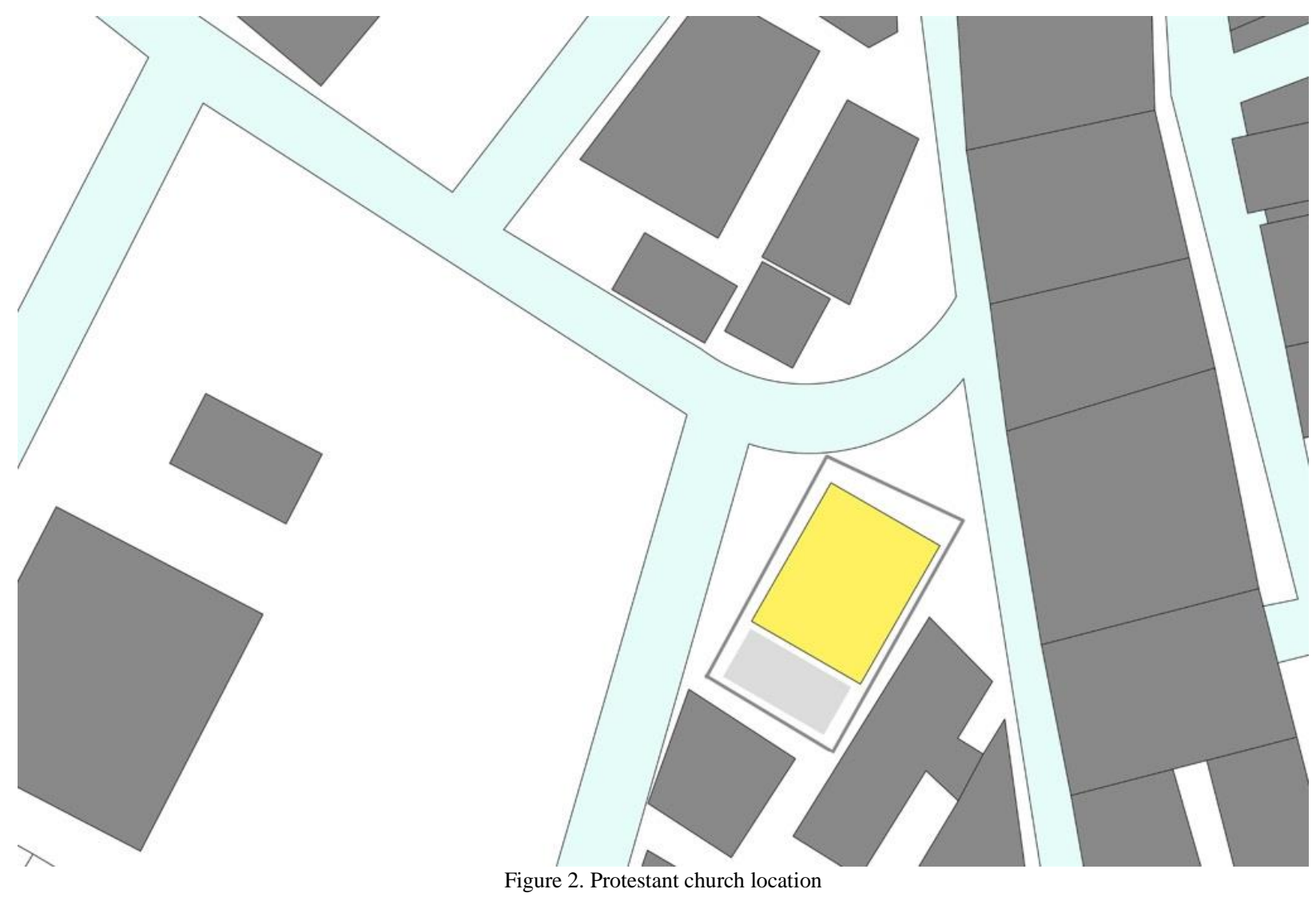

The church is built with three-story and every floor has a different function. The first floor is used as a cafe and has a second entrance from backyard. The second floor is used as the church. The third floor is used as a guesthouse serving for the usage of the church. All of the building is transformed into a church in 2000 .

The entrance door of the church is high and it opens to the entrance hall where the pictures of Jesus and Paul are exhibited. After the entrance, the church is reached by steps again. The place of worship has a rectangular plan and there is in Bema front of the apses. There are five rooms in the second floor and in the open area there are four 
columns and these columns make the church axis rectangular. On the right side of the apse, a staircase leading from the second floor to the upper and lower floors is located. The lower floor is used as a cafe and the upper floor is used as a guest house. The building was previously used as a bank and had been divided into several rooms prior to restoration work.

In the middle of the entrance facade is projected, and on the third floor there are three side-by-side rectangular windows and two small upper windows at the second floor level and there is one circular opening between them.

The church, which has a commercial and touristic area in its vicinity, attracts many tourists with this feature. A large number of tourists can participate in rituals whenever they want, there are no restrictions. The cafe, which belongs to the church, is an important source of income for the church. Being in the tourism region its visibility in terms of urban identity item is increased.

\section{Armenians in Hatay and Armenian Church}

Vakıflı Village is $4 \mathrm{~km}$ away from Samandağ province of Hatay and located in the foothill of Mountain Musa as a follow-up of Hidirbey Valley. The village was built in the 1800 s by the inhabiters of the villages Yoğunoluk and Hidirbey. In the mid-19th century, the villagers built a church with the money they collected among themselves in order to be able to worship. The building was used until 1915 and then used only at certain times as a church, then undergone a detailed restoration in 1997 and today it is essential for being the last Armenian village's church. (HatayŞehri Kutsalım)

The church is located in a mountainous area on a hillside with the view of a valley covered with lemon trees. (Figs. 3) The church has two bell towers and is made of masonry stone. The church is located in a courtyard. The courtyard is surrounded by an L type single-story church building and outbuildings. The church has a high height compared to the surrounding buildings. There is a guest in the courtyard and in front of this building villagers sell traditional food.

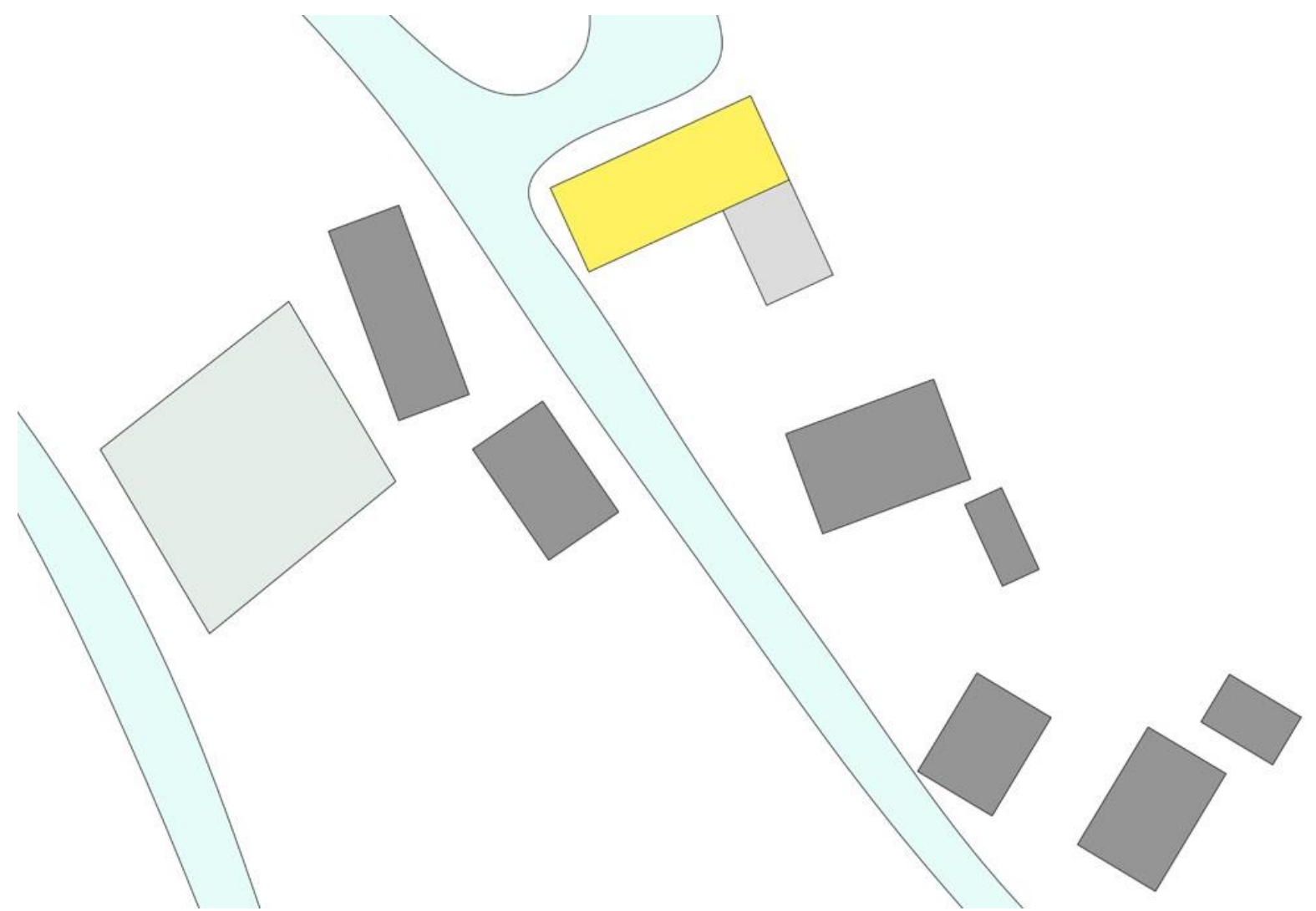

Figure 3. Armenian church location

The church has a basilical plan scheme with a single nave. The entrance is provided with a large door from the southern façade. The apse is raised one step higher from the entrance level. There is a circular skylight above the main worship space where the priest and his assistants pray. 
In the church, ceremony is performed every two weeks. The descendants of the Armenian, which are few in number, are trying to preserve their traditions and customs in the same way. Holy Birth, Holy Resurrection, the Feast of the Assumption of Virgin Mary and the name day of the church are still celebrated. In the immediate vicinity there is a tea garden, an Armenian cemetery and a few Armenian houses. In addition to its religious function, the church has been integrated into village life and is used as a village square, where the inhabitants of the village gather around their church. Villagers can sell their products, gather, entertain and celebrate.

\section{Conclusion}

Antakya, which dates back to ancient times, has hosted many different sects in terms of ethnic origin. The city, which has an important role in the spread of the Christian population, is an important historical environment for Christian communities. For Christians, whose number has disembarked in Antakya today, the church has not lost its meaning, but has become a social environment to transform it into a society that is closer to its traditions. Families who know each other are helping each other. In this study, Orthodox Church, Protestant Church and Armenian Church are examined. These cultural heritage belongings have a high contribution to the city in terms of cultural impact and are important structures where religious beliefs are gathered and spread amongst the indigenous people.

Today, there are 150 families affiliated to the Armenian Church, 200 families affiliated to the Orthodox Church, and the numbers of people who are affiliated to the Protestant Church cannot be determined because of the tourist visitors' population. For the disembarking number of Christians, the churches are popular among tourist attractions, which is an important factor in maintenance of these churches. In addition to its function as a church, the Armenian church has become a marketplace where people gather, communicate with tourists and sell organic materials which are produced in the village. The Orthodox Church is located on a major street, the Hürriyet Street, and the fact that tourists shop in the shops belonging to the church building makes a significant income for the church and increases the awareness of the church. The Protestant Church is an attraction center for being near to the Saray Street where there are cafes and shops, and the conversion of the ground floor into a cafe affiliated to the church has helped the church to gain profits.

Last but not least, a large number of tourists attend the rituals and find the chance to experience the Chorus, which is significant for Christianity. These structures, which are tried to be maintained by the communities with a small number of populations, form an important layer, a different character and a unique coexistence within the urban fabric of Antakya, and with the intended uses, it participates in other layers that present in the city as today's areas.

\section{References}

Eriş, M. and Çoruh, H. (2015). 81 İlde Kültür ve Şehir Hatay (2015) ( Culture and City in 81 Cities the city Hatay), İstanbul, Government of Hatay. Kireççi, R. (2001). Dinler ve Tarih Hazinesi (Religions and History Treasures). Hatay. Color Ofset.

Mısırlığlu, S. (2013). Şehr-i Kutsalım (2013) (Hatay, Holy City). Hatay. Antakya Belediyesi Kültür Yayınları.

Tekin, M. (2000). Hatay Tarihi (History of Hatay). Ankara. Atatürk Kültür Merkezi Başkanlığı Yayınları. 